\title{
EGFR NP_005219.2:p.H773_V774insG
}

National Cancer Institute

\section{Source}

National Cancer Institute. EGFR NP 005219.2:p.H773 V774insG. NCI Thesaurus. Code C98684.

An insertion of the amino acid glycine between the histidine at position 773 and the valine at position 774 of the epidermal growth factor receptor protein. 